\title{
Body image and quality of life in a Spanish population
}

This article was published in the following Dove Press journal:

International Journal of General Medicine

18 January 2011

Number of times this article has been viewed

\author{
Ignacio Jáuregui Lobera' \\ Patricia Bolaños Ríos ${ }^{2}$ \\ 'Department of Nutrition \\ and Bromatology, Pablo de \\ Olavide University, Seville, Spain; \\ ${ }^{2}$ Behavior Science Institute, \\ Seville, Spain
}

Correspondence: Ignacio Jáuregui Lobera Virgen del Monte 3I, Seville-4I0II, Spain. $\mathrm{Tel}+34954280789$

Fax +34 954278I67

Email ignacio-ja@telefonica.net
Purpose: The aim of the current study was to analyze the psychometric properties, factor structure, and internal consistency of the Spanish version of the Body Image Quality of Life Inventory (BIQLI-SP) as well as its test-retest reliability. Further objectives were to analyze different relationships with key dimensions of psychosocial functioning (ie, self-esteem, presence of psychopathological symptoms, eating and body image-related problems, and perceived stress) and to evaluate differences in body image quality of life due to gender.

Patients and methods: The sample comprised 417 students without any psychiatric history, recruited from the Pablo de Olavide University and the University of Seville. There were 140 men (33.57\%) and 277 women $(66.43 \%)$, and the mean age was 21.62 years ( $\operatorname{standard~deviation~}=5.12$ ) After obtaining informed consent from all participants, the following questionnaires were administered: BIQLI, Eating Disorder Inventory-2 (EDI-2), Perceived Stress Questionnaire (PSQ), Self-Esteem Scale (SES), and Symptom Checklist-90-Revised (SCL-90-R).

Results: The BIQLI-SP shows adequate psychometric properties, and it may be useful to determine the body image quality of life in different physical conditions. A more positive body image quality of life is associated with better self-esteem, better psychological wellbeing, and fewer eating-related dysfunctional attitudes, this being more evident among women.

Conclusion: The BIQLI-SP may be useful to determine the body image quality of life in different contexts with regard to dermatology, cosmetic and reconstructive surgery, and endocrinology, among others. In these fields of study, a new trend has emerged to assess body image-related quality of life.

Keywords: body appreciation, wellbeing, self-esteem, social functioning, gender differences

\section{Introduction}

Body image is a multidimensional construct that comprises self-perceptions and attitudes related to one's own body, mainly, but not limited, to one's physical appearance. ${ }^{1,2}$ The two facets of this construct, evaluation (ie, body satisfaction) and investment (in one's appearance and internalized appearance standards), are associated with psychosocial functioning. ${ }^{3}$ Body image attitudes are associated with self-esteem, eating behavior, sexual behavior, and emotional stability, for example, and the assessment of this multidimensional construct has typically ignored the influences of body image in specific life contexts. ${ }^{2,4,5}$ The increased prevalence of a negative body image, especially among women, has led researchers to investigate how such dissatisfaction may vary in the degree and nature of its impact on the individual's quality of life. In some cases (ie, people with body dysmorphic or eating disorders) the body image dissatisfaction may have penetrating consequences for quality of life and adverse 
psychosocial consequences, such as depression, social anxiety, impaired sexual functioning, and poor self-esteem. ${ }^{6}$ The main perspective on women's body image is that it is a general experience promulgated and reinforced by genderbiased cultural socialization. ${ }^{2,6}$

From the beginning of the 1990s, researchers have begun to develop disease-specific quality of life assessments to measure the psychosocial impact of body image. In the same way, body image assessments are needed to quantify pertinent facets of body image. ${ }^{7-9}$ In this field, general and focused instruments have been developed to measure bodyweight/body shape in particular physical conditions, and many researchers have developed tailored tools to assess body image-related problems. ${ }^{6,10,11}$ It has become necessary to design new instruments to assess the impact of one's body image on one's experiences in a variety of life domains. The main problem measuring the body image construct has been when considering it as a stable trait rather than as a situationally variable state. Regarding this bias, it is relevant to quantify the effects of one's body image on various self-experiences and life contexts. Following this idea, a recent emerging trend is the consideration of body image in relation to quality of life for a broad range of health conditions and disciplines, such as dermatology, oncology, endocrinology, or gynecology, among others. ${ }^{6}$

Based on this principle, the Body Image Quality of Life Inventory (BIQLI) was developed. ${ }^{6}$ The BIQLI is a self-reported questionnaire to quantify the influences of one's body image experiences on multiple relevant facets of psychosocial functioning and wellbeing in everyday life. It comprises 19 items that reflect specific domains referred to as day-to-day emotions, self-esteem, sexuality, social relationships, eating and exercise, grooming habits, and life satisfaction, among others. The BIQLI does not assess body image per se, rather the body image experiences on various psychosocial aspects of life. Regarding the psychometric properties of this instrument, results have indicated that mean comparisons may be conducted across all age and gender groups. ${ }^{12}$

Recent studies have investigated body image quality of life by means of the BIQLI. Some of them have focused on women with HIV. Compared with HIV-negative women, HIV-positive women presented poor body image quality of life. Moreover, compared with HIV-infected women without lipodystrophy, HIV-infected women with self-reported lipodystrophy presented poorer body image quality of life. ${ }^{13}$ Similar results were obtained among men with HIV. ${ }^{14}$ In other fields of study, the BIQLI has been used as a tool to measure any changes in body image, eg, among women before and after reconstructive surgery for pelvic organ prolapse. ${ }^{15}$

The aim of the current study was to analyze the psychometric properties, factor structure, and internal consistency of the Spanish version of the Body Image Quality of Life Inventory (BIQLI-SP) as well as its test-retest reliability. Further objectives were to analyze different relationships with key dimensions of psychosocial functioning (ie, self-esteem, presence of psychopathological symptoms, eating and body image-related problems, and perceived stress), and to evaluate differences in body image quality of life due to gender.

\section{Material and methods Participants}

The initial sample comprised 430 participants, but it was reduced to 417 after rejecting incomplete protocols. Regarding the BIQLI, only in two cases $(0.46 \%)$ was the questionnaire incomplete and therefore rejected; the rest of the protocols were rejected after other incomplete questionnaires were detected. Among the participants, nobody showed any comprehension and/or language difficulties. The final sample comprised 417 students (recruited from the Pablo de Olavide University and University of Seville) without any psychiatric history, which was assessed by means of a brief questionnaire at the moment of obtaining the informed consent. Moreover, this questionnaire included the self-reported height and weight of the participants in order to calculate the body mass index (BMI). In the group, there were 140 men (33.57\%) and 277 women (66.43\%), and the mean age was 21.62 years (standard deviation $[\mathrm{SD}]=5.12$ ).

Sample size was calculated taking into account the minimum recommended 10:1 ratio of number of participants to number of test items ${ }^{16}$ and the distribution of the courses and their schedules at the university.

\section{Measures \\ BIQLI}

The BIQLI is a self-reported questionnaire that comprises 19 items. To avoid pathology-oriented biases, ${ }^{17}$ those items are evaluated on a 7-point bipolar scale, from +3 (very positive effect) to 0 (no impact) to -3 (very negative effect). The BIQLI has shown high internal consistency (Cronbach's $\alpha=0.95$ ), good item validity of each item (correlations of $0.45-0.86$ ), and high stability over a $2-3$-week period (test-retest reliability $=0.79$ ). Moreover, the convergent validity of the BIQLI has been evidenced by its significant relationships with different standardized measures of body image. Regarding its factor structure, the 
best solution for the BIQLI reported a single-factor solution, the BIQLI being a unidimensional scale. In the original version it was considered as the major adverse impact when negative responses exceeded $25 \%$ of the sample.

\section{Eating Disorder Inventory-2 (EDI-2) ${ }^{18}$}

For this study, the body dissatisfaction (BD), bulimia (B), and drive for thinness (DT) subscales were administered. The BD subscale measures dissatisfaction with the overall shape and size of those parts of the body mostly related to eating disorders. The B subscale was designed to assess the tendency to think about and engage in overeating episodes. The DT subscale measures excessive concern with dieting, preoccupation with weight, and fear of weight gain. With regard to eating disorders, the DT subscale has been used as a screening test. The internal consistency of the test and its subscales ranges between 0.83 and 0.92 in patient samples and between 0.65 and 0.93 in various nonclinical samples. Test-retest reliability ranges between 0.41 and 0.97 , depending on the sample. Internal consistency of the $\mathrm{BD}, \mathrm{B}$, and DT subscales in this study was $>0.85$ for men and women.

\section{Perceived Stress Questionnaire (PSQ) ${ }^{19}$}

The Spanish version of the PSQ was used in this study. This questionnaire was designed to measure stress and comprised 30 items that differentially measured the general (PSQ-G) and recent (PSQ-R) forms of perceived stress. The validation study for the Spanish population showed excellent psychometric properties (internal consistency was 0.9 for the PSQ-G and 0.87 for the PSQ-R), and the questionnaire has been used in research, demonstrating good predictive value in stress-related diseases. Internal consistency in the current study was $>0.75$ for men and women.

\section{Self-Esteem Scale (SES) ${ }^{20}$}

The Spanish version of the SES was used in this study. The scale comprises 10 items that are scored using a Likert format (from "strongly agree" to "strongly disagree"): the higher the score, the higher the degree of self-esteem. The Spanish version of the instrument shows adequate internal consistency (Cronbach's $\alpha$ coefficient $=0.87$ ), test-retest reliability $(r=0.72)$, and construct validity. In this study, the internal consistency was 0.83 for men and 0.81 for women.

\section{Symptom Checklist-90-Revised (SCL-90-R) ${ }^{21}$}

The SCL-90-R is a 90-item self-report instrument and measures nine dimensions of psychological symptoms and yields three global indices of distress. The measured dimensions are somatization, obsessive-compulsive, interpersonal sensitivity, depression, phobic anxiety, hostility, paranoid ideation, and psychoticism. The ninth subscale refers to miscellaneous symptoms whose low factor loading prevents them from being included in the other subscales. Some sample items are "Feelings of being trapped or caught", "Feeling blocked in getting things done", and "Feeling no interest in things". The SCL-90-R also yields three global indices of distress that measure the severity of general psychopathology: 1) the Global Severity Index (GSI), which measures the degree of general distress; 2) Positive Symptom Total (PST), which refers to the number of symptoms reported by the subject; and 3) the Positive Symptom Distress Index, which measures the intensity of symptoms and relates general distress to the number of symptoms. The value of Cronbach's $\alpha$ coefficient ranges from 0.81 to 0.90 , and the instrument shows adequate concurrent and predictive validity. The Spanish version of the SCL-90-R was applied for this study. The internal consistency in the current study ranged between 0.77 and 0.89 for both genders.

\section{Procedure}

After obtaining informed consent from all participants, the abovementioned questionnaires were administered to the participants. This was carried out in group sessions of 10-15 participants per session, with no time limit and in the adequate context (ie, space in the classroom, light, noise, etc). A psychologist was present at the beginning of the session and explained how to complete the questionnaires. Having ensured that the instructions had been understood, the psychologist then left the room so as not to be present while the participants completed the questionnaires. The psychologist then returned at the end of the session. Participation was completely voluntary, and none of the participants received any form of recompense. It was left to each individual to decide whether they wished their responses to remain anonymous. The same conditions were applied 3 weeks later to obtain the test-retest reliability.

To apply the BIQLI-SP in our setting, the inventory underwent a translation/back-translation standard procedure. Twenty-five participants were randomly selected from the sample for preliminary testing to confirm that the items could be read and understood by them. During test administration, the participants were asked for their interpretations of the questions. Their suggestions and comments were then used to prepare the instructions and to ensure that the participants had no difficulties reading the items. The inventory is shown in Appendix A. 


\section{Statistical analysis}

Data were expressed as mean \pm SD. For the study of gender differences, we considered the proportion of men and women with positive and negative impact of body image, the analysis being developed by means of $\chi^{2}$. An analysis of variance (ANOVA) was conducted to study differences (gender) with respect to the responses obtained on the different items. Associations between variables were studied by means of the Pearson correlation coefficient. To ascertain the BIQLI-SP's factor structure, a principal component analysis with varimax rotation was conducted. The scree plot of eigenvalues $>1.0$ was taken into account, and Cronbach's $\alpha$ coefficient was used to determine the internal consistency of the BIQLI-SP. Finally, to test the one-factor model, a confirmatory factor analysis was performed.

\section{Results}

\section{Translation and back-translation}

A total of 19 out of the 25 participants who underwent the preliminary testing of the BIQLI-SP were bilingual and completed both the Spanish and the English version. The correlation between the English version scores and the Spanish version scores was 0.93 .

\section{Factor structure and internal consistency}

Taking into account a sample of 217 participants, an exploratory factor analysis was performed using principal component extraction with varimax rotation. Several indicators of the high degree of inter-relationship between the variables confirmed the relevance of this analysis. The Bartlett's test of sphericity gave $\chi^{2}=2543.93(P<0.0001)$, whereas the Kaiser-Meyer-Olkin (KMO) index of sample adequacy was 0.913 . The number of factors was determined by considering those with eigenvalues $>1$, as well as through examination of the scree plot. Items with a factor loading $\geq 0.45$ on a single factor were maintained. The best solution for the principal component analysis revealed a single-factor solution, with loadings of $0.542-0.841$, and the factor explaining $54.31 \%$ of the total variance.
The analysis of the internal consistency of the BIQLI-SP was determined by means of Cronbach's $\alpha$ coefficient. The BIQLI-SP, as a whole, yielded $\alpha=0.95$.

To test the one-factor model, a confirmatory factor analysis was performed, taking the sample of the rest of participants $(n=200)$. The one-factor structure was tested by means of a linear structural equation model. Following the recommendation to judge a model by a number of different criteria, ${ }^{18}$ the one-factor model fit satisfactorily, as shown in Table 1.

\section{Test-retest reliability}

The test-retest reliability of the mean score over the 3-week period was $r_{x x^{\prime}}=0.84$, indicating a positive and significant correlation between the two scores and showing an adequate temporal stability over the 3-week period. The paired samples $t$-test revealed no significant differences. Finally, the Cronbach's $\alpha$ coefficient gave a value of 0.90 in the second administration.

\section{Gender differences with reference to the percentages of participants reporting negative and positive effects}

The percentages of the participants who reported a negative (ie, ratings of $-3,-2$, or -1 ) or a positive impact of their body image (ie, ratings of $+1,+2$, or +3 ) are shown in Table 2. The areas of greatest adverse impact for women (ie, following the "exceeding $25 \%$ of the sample" cutoff point used in the original study) were feelings of personal adequacy and self-worth, social interaction with the other sex, day-to-day emotions, satisfaction with life, acceptability as a sexual partner, enjoyment of sex life, eating behavior, weight control, physical exercise, appearance, grooming activities, confidence in everyday life, and happiness in everyday life. In the case of men, the worst effect was reported with regard to the feelings of personal adequacy and self-worth, dayto-day emotions, satisfaction with life, and weight control. Taking into account the percentages of men and women reporting negative and positive effects of body image, there were significant differences with regard to day-to-day

Table I Confirmatory factor analysis of one-factor model of Body Image Quality of Life Inventory-Spanish Version

\begin{tabular}{|c|c|c|c|c|c|c|c|c|c|}
\hline \multirow[t]{2}{*}{ Model } & \multicolumn{3}{|c|}{ Model test } & \multicolumn{6}{|c|}{ Fit statistics } \\
\hline & $\chi^{2}$ & df & $\mathrm{Cmin} / \mathrm{df}$ & GFI & AGFI & RMR & TLI & CFI & RMSEA \\
\hline One-factor & 927.2 & 152 & 6.1 & 0.91 & 0.89 & 0.007 & 0.89 & 0.92 & 0.078 \\
\hline
\end{tabular}

Abbreviations: $\chi^{2}$, chi-square; df, degrees of freedom; Cmin/df, Chi-square/degrees of freedom; GFI, Goodness of Fit Index; AGFI, adjusted goodness of fit; RMR, root mean squared residual; TLI, Tucker-Lewis Index; CFI, Comparative Fit Index; RMSEA, root mean standard error of approximation. 
Table 2 Reports of negative and positive effects on the Body Image Quality of Life Inventory-spanish Version

\begin{tabular}{|c|c|c|c|c|}
\hline \multirow[t]{2}{*}{ BIQLI-SP items } & \multicolumn{2}{|c|}{$\begin{array}{l}\text { Percentage reporting } \\
\text { any negative effect }\end{array}$} & \multicolumn{2}{|c|}{$\begin{array}{l}\text { Percentage reporting } \\
\text { any positive effect }\end{array}$} \\
\hline & Women & Men & Women & Men \\
\hline $\begin{array}{l}\text { My basic feelings about myself } \\
\text { (feelings of personal adequacy and self-worth) }\end{array}$ & 36.4 & 26.5 & 42.8 & 50.0 \\
\hline $\begin{array}{l}\text { My feelings about my adequacy as a man or } \\
\text { woman (feelings of masculinity or femininity) }\end{array}$ & 23.2 & 11.1 & 52.8 & 57.8 \\
\hline My interactions with people of my own sex & 22.3 & 9.6 & 45.0 & $37.5^{\mathrm{a}}$ \\
\hline My interactions with people of the other sex & 26.2 & 15.7 & 52.8 & 64.9 \\
\hline My experiences when I meet new people & 24.0 & 15.0 & 45.7 & 54.1 \\
\hline My experiences at work or school & 22.0 & 20.9 & 46.3 & 55.2 \\
\hline My relationships with friends & 14.9 & 9.7 & 48.5 & 62.7 \\
\hline My relationships with family members & 14.9 & 11.8 & 44.8 & 58.1 \\
\hline My day-to-day emotions & 39.0 & 25.9 & 37.1 & $44.4^{*}$ \\
\hline My satisfaction with my life in general & 43.1 & 28.9 & 39.0 & 52.6 \\
\hline My feelings of acceptability as a sexual partner & 30.5 & 23.0 & 47.4 & 59.3 \\
\hline My enjoyment of my sex life & 30.0 & 17.8 & 42.2 & $54.8^{\mathrm{a}}$ \\
\hline My ability to control what and how much I eat & 34.9 & 16.0 & 36.8 & $47.3^{\mathrm{a}}$ \\
\hline My ability to control my weight & 37.5 & 25.4 & 33.0 & 41.0 \\
\hline My activities for physical exercise & 30.5 & 20.1 & 31.2 & $55.2^{\mathrm{b}}$ \\
\hline $\begin{array}{l}\text { My willingness to do things that might call } \\
\text { attention to my appearance }\end{array}$ & 32.3 & 12.8 & 25.9 & $40.6^{\mathrm{b}}$ \\
\hline $\begin{array}{l}\text { My daily "grooming" activities (ie, getting dressed } \\
\text { and physically ready for the day) }\end{array}$ & 30.2 & 14.0 & 42.6 & $55.1^{\mathrm{b}}$ \\
\hline How confident I feel in my everyday life & 41.8 & 18.4 & 36.6 & $50.0^{\mathrm{b}}$ \\
\hline How happy I feel in my everyday life & 32.5 & 23.7 & 41.9 & 54.1 \\
\hline
\end{tabular}

Notes: Percentages are based on those responding with negative $(-3,-2$, or -1$)$ or positive ratings $(+1,+2$, or +3$)$; ${ }^{\text {a }}<0.05$; ${ }^{\text {b }}<0.0 \mathrm{I}$.

emotions, enjoyment of sex life, eating behavior, physical exercise, appearance, grooming activities, and confidence in everyday life.

\section{Gender differences in the items of the BIQLI-SP}

As Table 3 shows, the mean of the impact of body image on the different aspects of social functioning was positive with regard to the men. In the case of women, there were six facets of that functioning in which women suffer a negative impact with reference to their body image: day-to-day emotions, satisfaction with life, weight control, physical exercise, appearance, and confidence in everyday life. The only facet in which there was no difference between women and men refers to experiences at work or school.

\section{Association between BIQLI-SP and the other variables}

For participant age, there was a negative and significant correlation with the score on the BIQLI-SP solely in the case of women $(r=-0.13 ; P<0.05)$. BMI was negatively and significantly correlated with the BIQLI-SP only in the case of women $(r=-0.20 ; P<0.01)$.
Pearson correlations were calculated between the BIQLI-SP and the rest of the psychological variables taken into account in the current study. Results are shown in Table 4. After controlling for BMI, partial correlations did not change significantly.

\section{Discussion}

The BIQLI-SP is useful to quantify the positive and negative impact of body image in different contexts regarding the quality of life. It is an instrument with excellent internal consistency, adequate test-retest reliability, and adequate validity, both convergent and discriminant. Its factor structure, as in a previous study, ${ }^{22}$ shows that the BIQLI-SP is a unidimensional measure without any subscales. Its internal consistency and test-retest reliability are adequate and similar to previous reports. ${ }^{6,23}$

With regard to the gender differences, there are some data that differ to those reported by Cash and Fleming in $2002 .{ }^{6}$ Considering the areas least negatively affected as those reported by less than $10 \%$ of the sample, there are no areas in the current study that may be classified following that cutoff point in the case of women. For men, only two areas can be considered as least negatively affected, 
Table 3 Gender differences in the items of the Body Image Quality of Life Inventory-Spanish Version

\begin{tabular}{|c|c|c|c|}
\hline \multirow[t]{2}{*}{ BIQLI-SP items } & \multicolumn{3}{|l|}{ Mean (SD) } \\
\hline & Women & Men & $\boldsymbol{F}$ \\
\hline $\begin{array}{l}\text { My basic feelings about myself (feelings of } \\
\text { personal adequacy and self-worth) }\end{array}$ & $0.04(1.67)$ & $0.46(1.59)$ & $5.73^{a}$ \\
\hline $\begin{array}{l}\text { My feelings about my adequacy as a man or } \\
\text { woman (feelings of masculinity or femininity) }\end{array}$ & $0.57(1.70)$ & $\mathrm{I} .0 \mathrm{I}(\mathrm{I} .5 \mathrm{I})$ & $6.59^{a}$ \\
\hline My interactions with people of my own sex & $0.51(1.62)$ & $0.88(1.49)$ & $4.73^{\mathrm{a}}$ \\
\hline My interactions with people of the other sex & $0.49(1.68)$ & $0.99(1.63)$ & $7.93^{\mathrm{b}}$ \\
\hline My experiences when I meet new people & $0.33(1.49)$ & $0.7 I(I .40)$ & $5.88^{\mathrm{a}}$ \\
\hline My experiences at work or school & $0.52(1.58)$ & $0.64(1.62)$ & 0.53 \\
\hline My relationships with friends & $0.80(1.54)$ & $\mathrm{I} .14(1.50)$ & $4.39^{a}$ \\
\hline My relationships with family members & $0.70(1.62)$ & $1.12(1.63)$ & $6.02^{\mathrm{a}}$ \\
\hline My day-to-day emotions & $-0.10(1.6 \mathrm{I})$ & $0.36(1.60)$ & $7.56^{\mathrm{b}}$ \\
\hline My satisfaction with my life in general & $-0.14(1.72)$ & $0.46(1.65)$ & $11.06^{b}$ \\
\hline My feelings of acceptability as a sexual partner & $0.31(1.77)$ & $0.74(\mathrm{I} .63)$ & $5.53^{\mathrm{a}}$ \\
\hline My enjoyment of my sex life & $0.32(1.82)$ & $0.80(1.56)$ & $6.91^{\mathrm{b}}$ \\
\hline My ability to control what and how much I eat & $0.05(1.57)$ & $0.54(1.43)$ & $8.99^{b}$ \\
\hline My ability to control my weight & $-0.14(1.5 \mathrm{I})$ & $0.32(1.45)$ & $8.59^{b}$ \\
\hline My activities for physical exercise & $-0.12(1.52)$ & $0.70(1.64)$ & $24.53^{b}$ \\
\hline $\begin{array}{l}\text { My willingness to do things that might call } \\
\text { attention to my appearance }\end{array}$ & $-0.17(1.40)$ & $0.42(1.24)$ & $16.60^{b}$ \\
\hline $\begin{array}{l}\text { My daily "grooming" activities (ie, getting } \\
\text { dressed and physically ready for the day) }\end{array}$ & $0.14(1.67)$ & $0.72(\mathrm{I} .33)$ & $12.19^{\mathrm{b}}$ \\
\hline How confident I feel in my everyday life & $-0.14(1.66)$ & $0.53(1.47)$ & $15.82^{\mathrm{b}}$ \\
\hline How happy I feel in my everyday life & $0.11(1.69)$ & $0.58(1.74)$ & $6.70^{\mathrm{a}}$ \\
\hline BIQLI total & $4.01(22.82)$ & 13.04 (19.89) & $15.36^{\mathrm{b}}$ \\
\hline BIQLI mean & $0.22(1.21)$ & $0.69(1.05)$ & $14.68^{b}$ \\
\hline
\end{tabular}

Notes: ${ }^{\mathrm{a} P}<0.05 ;{ }^{\mathrm{b}} \mathrm{P}<0.01$.

those being "interactions with people of my own sex" and "my relationships with friends". The different context and the period of time between the two studies could explain the differences as well as the fact that Cash and Fleming did not distinguish the gender in their results on the reports of the effects of body image. In another study ${ }^{23}$ it was found that men had a significantly more positive body image quality of life than did women. In this case, the current study confirms this result, but the means in both men and women are lower than those reported in 2004. Despite the different context, this decrease could be indicating a worse quality of life related to body image 6 years later. In fact, from the 1990s, research findings highlight the growing prevalence of a negative body image. ${ }^{24-26}$

Regarding the association between the BIQLI-SP and other variables, the current study shows clearly that there is a negative correlation between body image quality of life and the eating disorder-related variables of the EDI-2 (between -0.30 and -0.54 ). This result confirms the data reported in a previous study by means of the Eating Attitudes Test (EAT-26). ${ }^{23}$ Nevertheless, the association was found to be significant only in women, which differs from the results of Cash et al. ${ }^{23}$ Sociocultural differences could explain the different present finding, as reported in a previous study. ${ }^{27}$

Taking into account the different variables that were measured in the current study by means of the SCL-90-R, it has been found that interpersonal sensitivity was negatively correlated to body image quality of life, once again only in the sample of women. The interpersonal sensitivity subscale of the SCL-90-R focuses on feelings of discomfort and negative expectancies in interpersonal situations, as well as feelings of inferiority in comparison with others. In former studies, interpersonal sensitivity has been found to be correlated to eating-related and body image-related problems in both women and men. ${ }^{28,29}$ Despite affective and general psychopathology-related characteristics usually failing to be predictive of body image disturbances,${ }^{30}$ the current study shows that body image quality of life is related to some global indexes of the SCL-90-R, such as the GSI, which measures the degree of general distress, and the PST, which refers to the number of symptoms reported by the subjects.

As in the Cash et al study, ${ }^{23}$ a strong and positive association has been found between body image quality of life and self-esteem in both men and women. The higher association 
Table 4 Correlations between the Body Image Quality of Life Inventory-Spanish Version and other psychological variables among men and women

\begin{tabular}{|c|c|c|}
\hline \multirow[t]{2}{*}{ Variable } & \multicolumn{2}{|c|}{ BIQLI-SP } \\
\hline & Men & Women \\
\hline \multicolumn{3}{|l|}{$\begin{array}{l}\text { Eating Disorder Inventory } \\
\text { (EDI-2) }\end{array}$} \\
\hline Drive for thinness & -0.15 & $-0.54^{a}$ \\
\hline Bulimia & -0.04 & $-0.30^{\mathrm{a}}$ \\
\hline Body dissatisfaction & -0.04 & $-\left.0.4\right|^{\mathrm{a}}$ \\
\hline \multirow{2}{*}{\multicolumn{3}{|c|}{$\begin{array}{l}\text { Perceived Stress Questionnaire } \\
\text { (PSQ) }\end{array}$}} \\
\hline & & \\
\hline General & -0.06 & 0.17 \\
\hline Recent & -0.04 & -0.10 \\
\hline Self-esteem scale & $0.40^{\mathrm{a}}$ & $0.43^{\mathrm{a}}$ \\
\hline \multirow{2}{*}{\multicolumn{3}{|c|}{$\begin{array}{l}\text { Symptom Checklist-90-Revised } \\
\text { (SCL-90-R) }\end{array}$}} \\
\hline & & \\
\hline Somatization & 0.08 & -0.06 \\
\hline Obsessive-compulsive & 0.06 & 0.03 \\
\hline Interpersonal sensitivity & -0.03 & $-0.13^{b}$ \\
\hline Depression & 0.05 & 0.02 \\
\hline Phobic anxiety & 0.05 & 0.03 \\
\hline Hostility & -0.04 & -0.08 \\
\hline Paranoid ideation & 0.02 & 0.05 \\
\hline Psychoticism & 0.04 & -0.03 \\
\hline Global Severity Index (GSI) & -0.07 & $-0.17^{a}$ \\
\hline Positive Symptom Total (PST) & $-0.22^{\mathrm{a}}$ & $-0.19^{a}$ \\
\hline Positive Symptom Distress Index (PSDI) & 0.07 & 0.07 \\
\hline
\end{tabular}

Notes: ${ }^{\mathrm{P}} \mathrm{P}<0.01$; ${ }^{\mathrm{b} P}<0.05$.

between body image quality of life and self-esteem reported in that study could again be explained by sociocultural differences based on the evidence that beauty ideals and body concerns vary among cultures..$^{30}$

Summarizing, it seems that a more positive body image quality of life is associated with better self-esteem, better psychological wellbeing, and fewer eating-related dysfunctional attitudes, this being clearer among women.

Despite there being a negative but weak correlation between age and body image quality of life in women, this is not a surprising finding, taking into account earlier studies. Thus, it has been observed that younger women have more positive ratings of appearance satisfaction than older women do. With regard to body image, despite the most discussed developmental period being puberty, other periods of developmental transition may be relevant as well, such as early childhood, pregnancy, and middle or later life. ${ }^{30}$

The BIQLI-SP shows adequate psychometric properties and may be useful in determining the body image quality of life in different physical conditions with regard to dermatology, cosmetic and reconstructive surgery, and endocrinology, among others. In these fields of study, a new trend has emerged in order to assess body image-related quality of life. ${ }^{31-36}$

Despite the present study supporting the reliability and validity of the BIQLI-SP, it has some limitations. BMI was calculated based on self-reported height and weight of the participants. Nevertheless, this may be a small limitation, taking into account that self-reported heights and weights have been shown to be extremely reliable for epidemiological studies. ${ }^{37}$ On the other hand, this point cannot be compared with the study of Cash et al, ${ }^{18}$ due to the fact that in that study the procedure to assess the weight and height of the participants was not mentioned. The fact that all participants were university students could be another limitation, so that it would be necessary to apply the BIQLI-SP with more diverse samples, both community and clinical (ie, eating disorder patients). As discussed by Cash et al, ${ }^{23}$ numerous medical conditions and treatments have a negative effect on body image functioning and their associated psychological consequences. In this sense, future research could be focused on such medical populations.

\section{Conclusion}

The BIQLI-SP may be useful to determine body image quality of life in different contexts with regard to dermatology, cosmetic and reconstructive surgery, and endocrinology, among others. In these fields of study, a new trend has emerged in order to assess body image-related quality of life.

\section{Acknowledgment}

We acknowledge the support of the EDUBSI (Eating Disorders Unit of the Behavioural Sciences Institute), which supported the preparation of this manuscript.

\section{Disclosure}

The authors state that there are no conflicts of interest. This research received no specific grant from any funding agency in the public, commercial, or nonprofit sectors.

We hereby state that it is an original publication, and the manuscript has not been previously submitted or published elsewhere. IJL carried out the literature research and wrote the manuscript, and PBR provided critical input and corrections for the outline and writing of the manuscript. All authors read and approved the final manuscript.

\section{References}

1. Cash TF, Pruzinsky T, editors. Body Image: A Handbook of Theory, Research, and Clinical Practice. New York, NY: Guilford Press; 2002.

2. Thompson JK, Heinberg LJ, Altabe M, Tantleff-Dunn S. Exacting Beauty: Theory, Assessment, and Treatment of Body Image Disturbance. Washington, DC: American Psychological Association; 1999. 
3. Cash TF. Cognitive-behavioural perspectives on body image. In: Cash TF, Pruzinsky T, editors. Body Image: A Handbook of Theory, Research, and Clinical Practice. New York, NY: Guilford Press; 2002:38-46.

4. Cash TF. The psychology of physical appearance: aesthetics, attributes, and images. In: Cash TF, Pruzinsky T, editors. Body Images: Development, Deviance, and Change. New York: Guilford Press; 1990:51-79.

5. Cash TF. Body image attitudes: evaluation, investment, and affect. Percept Mot Skills. 1994;78:1168-1170.

6. Cash TF, Fleming EC. The impact of body image experiences: development of the body image quality of life inventory. Int $J$ Eat Disord. 2002;31:455-460.

7. Spilker B, editor. Quality of Life Assessments in Clinical Trials. New York, NY: Raven Press; 1990.

8. Pruzinsky T. Enhancing quality of life in medical populations: a vision for body image assessment and rehabilitation as standards of care. Body Image. 2004;1:71-81.

9. Pruzinsky T, Cash TF. Assessing body image and quality of life in medical settings. In: Cash TF, Pruzinsky T, editors. Body image: A Handbook of Theory, Research, and Clinical Practice. New York, NY: Guilford Press; 2002:171-179.

10. Gardner RM. Body image assessment of children. In: Cash TF, Pruzinsky T, editors. Body Image: A Handbook of Theory, Research, and Clinical Practice. New York, NY: Guilford Press; 2002:127-134.

11. Thompson JK, van den Berg P. Measuring body image attitudes among adolescents and adults. In: Cash TF, Pruzinsky T, editors. Body Image: A Handbook of Theory, Research, and Clinical Practice. New York, NY: Guilford Press; 2002;142-154.

12. Rusticus SA, Hubley AM, Zumbo BD. Measurement invariance of the appearance schemas inventory-revised and the body image quality of life inventory across age and gender. Assessment. 2008;15:60-71.

13. Huang JS, Harrity S, Lee D, Becerra K, Santos R, Mathews WC. Body image in women with HIV: a cross-sectional evaluation. AIDS Res Ther. 2006;6:3-17.

14. Huang JS, Lee D, Becerra K, Santos R, Barber E, Mathews WC. Body image in men with HIV. AIDS Patient Care STDS. 2006;20:668-677.

15. Lowder JL, Ghetti C, Moalli P, Zyczynski H, Cash TF. Body image in women before and after reconstructive surgery for pelvic organ prolapse. Int Urogynecol J Pelvic Floor Dysfunct. 2010;21:919-925.

16. Kline RB. Principles and practices of structural equation modelling. In: Kenny DA, editor. Methodology in the Social Sciences. New York: Guilford Press; 1998.

17. Seligman ME, Csikszentmihalyi M. Positive psychology. An introduction. Am Psychol. 2000;55:5-14.

18. Garner DM. Inventario de trastornos de la conducta alimentaria-2. Madrid: Tea Ediciones; 1998

19. Sanz-Carrillo C, García-Campayo J, Rubio A, Santed MA, Montoro M. Validation of the Spanish version of the PSQ (perceived stress questionnaire). J Psychosom Res. 2002;52:167-172.

20. Vázquez AJ, Jiménez R, Vázquez-Morejón R. Spanish valitation of Rosenberg's Selef-esteem Scale (SES). Apuntes de Psicología. 2004;22:247-255.
21. González de Rivera JL, Derogatis LR, de las Cuevas C, et al. The Spanish version of the SCL-90-R. Normative data in the general population. Towson: Clinical Psychometric Research; 1989.

22. Breivik E, Olsson U. Adding variables to improve fit: the effect of model size on fit assessment in LISREL. In: Cudeck R, du Toit S, Sörbom D, editors. Structural Equation Modeling. Lincolnwood: Scientific Software International; 2001:169-194.

23. Cash TF, Jakatdar TA, Fleming E. The body image quality of life inventory: further validation with college men and women. Body Image. 2004;1:279-287.

24. Cash TF. The Body Image Workbook: An 8-Step Program for Learning to Like your Looks. Oakland, CA: New Harbinger; 1997.

25. Feingold A, Mazzella R. Gender differences in body image are increasing. Psychol Sci. 1998;9:190-195.

26. Garner DM. The 1997 body image survey results. Psychology Today. 1997; 1:30-44, 75-80, 84.

27. Toro J, Gila A, Castro J, Pombo C, Guete O. Body image, risk factors for eating disorders and sociocultural influences in Spanish adolescents. Eating Weight Disord. 2005;10:91-97.

28. Atlas JG. Interpersonal sensitivity, eating disorder symptoms, and eating/thinness expectancies. Current Psychol. 2004;22:368-378.

29. McFarland MB, Karninsky PL. Men, muscles, and mood: the relationship between selfconcept, dysphoria, and body image disturbances. Eat Behav. 2009;10:68-70.

30. Wertheim EH, Paxton SJ, Blaney S. Risk factors for the development of body image disturbances. In: Thompson JK, editor. Handbook of Eating Disorders and Obesity. Hoboken, NJ: John Wiley and Sons; 2004: 463-494.

31. Koo JYM, Yeung J. Body image issues in dermatology. In: Cash TF, Pruzinsky T, editors. Body Image: A Handbook of Theory, Research, and Clinical Practice. New York, NY: Guilford Press; 2002:333-341.

32. Pruzinsky T. Body image adaptation to reconstructive surgery for acquired disfigurement. In: Cash TF, Pruzinsky T, editors. Body Image: A Handbook of Theory, Research, and Clinical Practice. New York, NY: Guilford Press; 2002:440-449.

33. Rumsey N. Body image and congenital conditions with visible differences. In: Cash TF, Pruzinsky T, editors. Body Image: A Handbook of Theory, Research, and Clinical Practice. New York, NY: Guilford Press; 2002:226-233.

34. Rumsey N, Harcourt D. Body image and disfigurement: issues and interventions. Body Image. 2004;1:83-97.

35. Sarwer DB. Cosmetic surgery and changes in body image. In: Cash TF, Pruzinsky T, editors. Body Image: A Handbook of Theory, Research, and Clinical Practice. New York, NY: Guilford Press; 2002: 422-430.

36. Gilmour J. Body image issues in endocrinology. In: Cash TF, Pruzinsky T, editors. Body Image: A Handbook of Theory, Research, and Clinical Practice. New York, NY: Guilford Press; 2002:370-378.

37. Strauss RS. Comparison of measured and self-reported weight and height in a cross-sectional sample of young adolescents. Int J Obes Relat Metab Disord. 1999;23:904-908. 


\section{Appendix A \\ Body Image Quality of Life Inventory-Spanish Version (BIQLI-SP)}

Las personas tenemos diferentes percepciones y sentimientos sobre nuestra apariencia física. Esto es lo que se denomina "Imagen corporal". Algunas personas se sienten satisfechas, en general, con su aspecto, mientras que otras no lo están. Además, las personas diferimos en el modo en que nuestra imagen corporal afecta a los distintos aspectos de nuestras vidas. En este sentido, la imagen corporal puede tener efectos positivos o negativos, o bien no afectar de ningún modo a nuestras vidas.

A continuación presentaremos distintos aspectos de su vida en los que puede influir su imagen corporal (columna izquierda). Por favor, rodee con un círculo, en la columna de la derecha que corresponda, el grado en que su imagen corporal afecta a dichos aspectos. Le rogamos que trate de ser lo más exacto y sincero posible cuando emita sus respuestas.

\begin{tabular}{|c|c|c|c|c|c|c|c|}
\hline \multirow{2}{*}{$\begin{array}{l}\text { Mi imagen corporal } \\
\text { afecta a... }\end{array}$} & \multicolumn{7}{|c|}{ Grado de afectación } \\
\hline & $\begin{array}{l}\text { De manera } \\
\text { muy negativa }\end{array}$ & $\begin{array}{l}\text { De manera } \\
\text { moderada- } \\
\text { mente negativa }\end{array}$ & $\begin{array}{l}\text { De manera } \\
\text { ligeramente } \\
\text { negativa }\end{array}$ & $\begin{array}{l}\text { No tiene } \\
\text { ningún } \\
\text { efecto }\end{array}$ & $\begin{array}{l}\text { De manera } \\
\text { ligeramente } \\
\text { positiva }\end{array}$ & $\begin{array}{l}\text { De manera } \\
\text { moderada- } \\
\text { mente positiva }\end{array}$ & $\begin{array}{l}\text { De manera } \\
\text { muy positiva }\end{array}$ \\
\hline $\begin{array}{l}\text { I. Cómo me siento } \\
\text { básicamente a mi } \\
\text { mismo (es decir, a mis } \\
\text { sentimientos de ser una } \\
\text { persona adecuada } \\
\text { y valiosa) }\end{array}$ & -3 & -2 & -1 & 0 & +1 & +2 & +3 \\
\hline $\begin{array}{l}\text { 2. Mis sentimientos } \\
\text { de ser una persona } \\
\text { adecuada como hombre } \\
\text { o mujer (es decir, } \\
\text { a mis sentimientos } \\
\text { de masculinidad o } \\
\text { feminidad) }\end{array}$ & -3 & -2 & -1 & 0 & +1 & +2 & +3 \\
\hline $\begin{array}{l}\text { 3. Mis relaciones con } \\
\text { personas del mismo } \\
\text { sexo }\end{array}$ & -3 & -2 & -1 & 0 & +1 & +2 & +3 \\
\hline $\begin{array}{l}\text { 4. Mis relaciones con } \\
\text { personas del otro sexo }\end{array}$ & -3 & -2 & -1 & 0 & +1 & +2 & +3 \\
\hline $\begin{array}{l}\text { 5. Mis experiencias con } \\
\text { la gente nueva que } \\
\text { conozco }\end{array}$ & -3 & -2 & -1 & 0 & +1 & +2 & +3 \\
\hline $\begin{array}{l}\text { 6. Mis experiencias en el } \\
\text { trabajo o en la escuela }\end{array}$ & -3 & -2 & -1 & 0 & +1 & +2 & +3 \\
\hline $\begin{array}{l}\text { 7. Mis relaciones con } \\
\text { amigos }\end{array}$ & -3 & -2 & -1 & 0 & +1 & +2 & +3 \\
\hline $\begin{array}{l}\text { 8. Mis relaciones con los } \\
\text { miembros de mi familia }\end{array}$ & -3 & -2 & -1 & 0 & +1 & +2 & +3 \\
\hline $\begin{array}{l}\text { 9. Mis emociones } \\
\text { cotidianas }\end{array}$ & -3 & -2 & -1 & 0 & +1 & +2 & +3 \\
\hline $\begin{array}{l}\text { 10. La satisfacción con mi } \\
\text { propia vida en general }\end{array}$ & -3 & -2 & -1 & 0 & +1 & +2 & +3 \\
\hline $\begin{array}{l}\text { II. Mis sentimientos como } \\
\text { compañero sexual } \\
\text { (es decir, a mis } \\
\text { sentimientos sobre } \\
\text { ser aceptado como } \\
\text { compañero sexual) }\end{array}$ & -3 & -2 & I & 0 & +1 & +2 & +3 \\
\hline $\begin{array}{l}\text { 12. El disfrute con mi vida } \\
\text { sexual }\end{array}$ & -3 & -2 & -1 & 0 & +1 & +2 & +3 \\
\hline $\begin{array}{l}\text { 13. Mi capacidad de } \\
\text { controlar qué y cuánto } \\
\text { como }\end{array}$ & -3 & -2 & -1 & 0 & +1 & +2 & +3 \\
\hline
\end{tabular}




\begin{tabular}{|c|c|c|c|c|c|c|c|}
\hline \multirow{2}{*}{$\begin{array}{l}\text { Mi imagen corporal } \\
\text { afecta a... }\end{array}$} & \multicolumn{7}{|c|}{ Grado de afectación } \\
\hline & $\begin{array}{l}\text { De manera } \\
\text { muy negativa }\end{array}$ & $\begin{array}{l}\text { De manera } \\
\text { moderada- } \\
\text { mente negativa }\end{array}$ & $\begin{array}{l}\text { De manera } \\
\text { ligeramente } \\
\text { negativa }\end{array}$ & $\begin{array}{l}\text { No tiene } \\
\text { ningún } \\
\text { efecto }\end{array}$ & $\begin{array}{l}\text { De manera } \\
\text { ligeramente } \\
\text { positiva }\end{array}$ & $\begin{array}{l}\text { De manera } \\
\text { moderada- } \\
\text { mente positiva }\end{array}$ & $\begin{array}{l}\text { De manera } \\
\text { muy positiva }\end{array}$ \\
\hline $\begin{array}{l}\text { 14. Mi capacidad de } \\
\text { controlar mi peso }\end{array}$ & -3 & -2 & -1 & 0 & +1 & +2 & +3 \\
\hline $\begin{array}{l}\text { 15. Mis actividades o } \\
\text { prácticas de ejercicio } \\
\text { físico }\end{array}$ & -3 & -2 & -1 & 0 & +1 & +2 & +3 \\
\hline $\begin{array}{l}\text { 16. Mis ganas de hacer } \\
\text { cosas que podrían } \\
\text { Ilamar la atención sobre } \\
\text { mi apariencia }\end{array}$ & -3 & -2 & -1 & 0 & +1 & +2 & +3 \\
\hline $\begin{array}{l}\text { 17. Mis actividades diarias } \\
\text { de acicalamiento } \\
\text { (p. ej., al vestirme o } \\
\text { arreglarme) }\end{array}$ & -3 & -2 & -1 & 0 & +1 & +2 & +3 \\
\hline $\begin{array}{l}\text { 18. La medida en que me } \\
\text { siento seguro/a de mi } \\
\text { mismo/a en mi vida } \\
\text { diaria }\end{array}$ & -3 & -2 & -1 & 0 & +1 & +2 & +3 \\
\hline $\begin{array}{l}\text { 19. La medida en que me } \\
\text { siento feliz en mi vida } \\
\text { diaria }\end{array}$ & -3 & -2 & -1 & 0 & +1 & +2 & +3 \\
\hline
\end{tabular}

International Journal of General Medicine

\section{Publish your work in this journal}

The International Journal of General Medicine is an international, peer-reviewed open-access journal that focuses on general and internal medicine, pathogenesis, epidemiology, diagnosis, monitoring and treatment protocols. The journal is characterized by the rapid reporting of reviews, original research and clinical studies across all disease areas.
A key focus is the elucidation of disease processes and management protocols resulting in improved outcomes for the patient.The manuscript management system is completely online and includes a very quick and fair peer-review system. Visit http://www.dovepress.com/ testimonials.php to read real quotes from published authors.

Submit your manuscript here: http://www.dovepress.com/international-journal-of-general-medicine-journal 